\title{
IceMole: a maneuverable probe for clean in situ analysis and sampling of subsurface ice and subglacial aquatic ecosystems
}

\author{
Bernd DACHWALD, ${ }^{1}$ Jill MIKUCKI, ${ }^{2}$ Slawek TULACZYK, ${ }^{3}$ Ilya DIGEL, ${ }^{4}$ Clemens ESPE, ${ }^{1}$ \\ Marco FELDMANN, ${ }^{1}$ Gero FRANCKE, ${ }^{1}$ Julia KOWALSKI, ${ }^{1}$ Changsheng $\mathrm{XU}^{1}{ }^{*}$ \\ ${ }^{1}$ Faculty of Aerospace Engineering, FH Aachen University of Applied Sciences, Aachen, Germany \\ E-mail: dachwald@fh-aachen.de \\ ${ }^{2}$ Department of Microbiology, University of Tennessee, Knoxville, TN, USA \\ ${ }^{3}$ Department of Earth and Planetary Sciences, University of California Santa Cruz, Santa Cruz, CA, USA \\ ${ }^{4}$ Institute of Bioengineering, FH Aachen University of Applied Sciences, Jülich, Germany
}

\begin{abstract}
There is significant interest in sampling subglacial environments for geobiological studies, but they are difficult to access. Existing ice-drilling technologies make it cumbersome to maintain microbiologically clean access for sample acquisition and environmental stewardship of potentially fragile subglacial aquatic ecosystems. The IceMole is a maneuverable subsurface ice probe for clean in situ analysis and sampling of glacial ice and subglacial materials. The design is based on the novel concept of combining melting and mechanical propulsion. It can change melting direction by differential heating of the melting head and optional side-wall heaters. The first two prototypes were successfully tested between 2010 and 2012 on glaciers in Switzerland and Iceland. They demonstrated downward, horizontal and upward melting, as well as curve driving and dirt layer penetration. A more advanced probe is currently under development as part of the Enceladus Explorer (EnEx) project. It offers systems for obstacle avoidance, target detection, and navigation in ice. For the EnEx-IceMole, we will pay particular attention to clean protocols for the sampling of subglacial materials for biogeochemical analysis. We plan to use this probe for clean access into a unique subglacial aquatic environment at Blood Falls, Antarctica, with return of a subglacial brine sample.
\end{abstract}

KEYWORDS: Antarctic glaciology, extraterrestrial glaciology, glaciological instruments and methods, subglacial exploration geophysics, subglacial lakes

\section{INTRODUCTION}

The IceMole is a novel, maneuverable, subsurface ice probe for clean in situ analysis and sampling of ice and subglacial materials (Mann, 2010; Dachwald and others, 2011, 2012). It has been developed and constructed at the $\mathrm{FH}$ Aachen University of Applied Sciences' Astronautical Laboratory. Clean samples are collected with a hollow ice screw (as used in mountaineering) at the tip of the probe. Maneuverability is achieved with a differentially heated melting head and optional side-wall heaters. The first prototype, IceMole 1, was successfully tested on Morteratschgletscher, Switzerland, in 2010, and a second prototype, IceMole 2, on Morteratschgletscher and on Hofsjökull ice cap, Iceland, in 2012. The current design of the IceMole is adapted to subsurface investigation of terrestrial glaciers and ice sheets, but a future goal is to develop it for extraterrestrial missions. In February 2012, a university research consortium led by FH Aachen University of Applied Sciences received funding from the German DLR Space Administration to develop a more advanced IceMole probe (Dachwald and others, 2013a). A key aim of this Enceladus Explorer (EnEx) project is to develop a probe, EnEx-IceMole, that can penetrate tens of meters below terrestrial ice surfaces with autonomous inice navigation and sample-recovery capabilities. Therefore, the EnEx-IceMole includes sophisticated systems for obstacle avoidance, target detection, and navigation in ice. This

*Present address: Siemens AG, Mülheim, Germany. is seen as an important step towards the exploration of the Solar System's icy moons, such as the Saturnian moon Enceladus, the project's namesake. The astrobiologically most interesting icy environments in the Solar System are (1) the polar caps of Mars (Tokano, 2005; Jakosky and others, 2007), (2) the icy crust of Jupiter's moon Europa and its putative ocean below (Greenberg, 2005; Chyba and Phillips, 2007; Pappalardo and others, 2009) and (3) the icy crust of Saturn's moon Enceladus, also with putative saltwater reservoirs or even a global ocean below (Parkinson and others, 2007; Postberg and others, 2011).

Enceladus is, despite its small size (diameter $\sim 500 \mathrm{~km}$ ), one of the most geologically dynamic bodies in the Solar System (Kargel, 2006). Its surface is dominated by water ice (Hendrix and others, 2010) with an average temperature of $\sim 51 \mathrm{~K}$ (Cruikshank and others, 2005). The Cassini spacecraft has identified a geologically young region (possibly as young as $5 \times 10^{5}$ years) with elevated temperatures $(145 \mathrm{~K}$ and higher) at the south pole. Four linear depressions in this geologically active region, dubbed tiger stripes because of their appearance in the infrared, spray plumes of water, including simple organic compounds (Waite and others, 2009), via cryovolcanism (Fig. 1).

Analysis of the plume material strongly suggests that it originates from a body of liquid salt-water (Postberg and others, 2011) or even a global ocean (Patthoff and Kattenhorn, 2011) below the icy crust. The unique chemistry found in the plumes has fueled speculation that Enceladus may harbor life (Parkinson and others, 2007; McKay and others, 


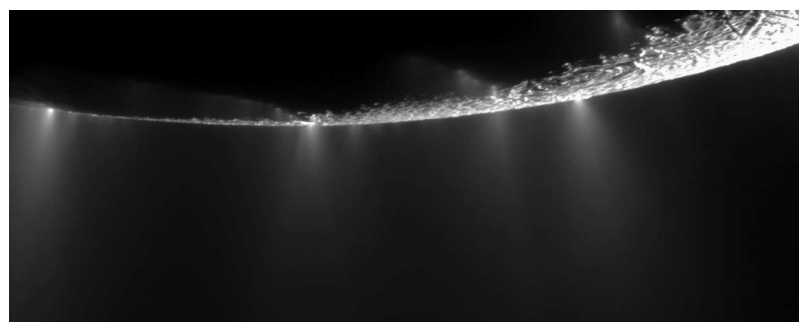

Fig. 1. Plumes spray water ice out from many locations along the tiger stripes near the south pole of Enceladus. Image credit: NASA/ Jet Propulsion Laboratory (JPL)/Space Science Institute.

2008). A lander mission equipped with a subsurface icemelting probe may help to resolve this question. Landing on the rough terrain close to the tiger-stripe cracks from which the plumes emanate, however, is considered highly risky (see Fig. 2), so a probe that lands at a safe distance from a crack and melts its way to the inner wall to analyze the plume material in situ would be desirable.

After deployment of a melting probe on the icy surface of Enceladus, the probe would encounter a largely unknown environment in the ice, which may contain obstacles (e.g. fragments of meteorites and shallow cracks), all of which must be avoided. This is only possible if the probe is steerable and able to sense obstacles in its immediate environment. To navigate in ice, a steerable probe also has to know its position and attitude (i.e. orientation) without external references such as stars, a magnetic field or a global navigation system. The attitude and position has to be measured on board with respect to an ad hoc local reference frame. Key information about the astrobiological potential of these icy environments will come from the analysis of materials embedded in or underneath the surface ice layers (Dachwald and others, 2013b), sampled by an IceMole-like probe. The development of a fully capable ice-penetrating probe for an astrobiological mission to Enceladus, or another icy body in the Solar System, will be a long, multistage process with each phase aimed at optimizing different capabilities of the probe. The particular emphases of the current phase include (1) in-ice maneuverability, (2) in-ice obstacle avoidance and targeting, and (3) clean acquisition of a liquid sample.

The MIDGE (Minimally Invasive Direct Glacial Exploration) project, funded by the US National Science Foundation (NSF), is an international collaboration with the EnEx consortium that will use the EnEx-IceMole to cleanly collect samples from an Antarctic glacial brine body, known as Blood Falls, for chemical and microbiological analyses. Blood Falls, McMurdo Dry Valleys, East Antarctica, is a unique glacial feature where subglacial liquid is released to the surface through a crevasse, making it a terrestrial analog to the tiger stripes on Enceladus. It is the only location in Antarctica where significant volumes (thousands of cubic meters) of subglacial water are forced to the surface where they can be sampled and investigated without deep drilling. Our planned sampling in Antarctica is an important step in demonstrating the capabilities of the IceMole for astrobiological investigations. The EnEx-IceMole was tested on Morteratschgletscher in June 2013. In November/December 2013, it will be further tested for its ability to collect deep samples cleanly on Canada Glacier, McMurdo Dry Valleys, prior to its planned deployment at Blood Falls in the 2014/15 austral summer.

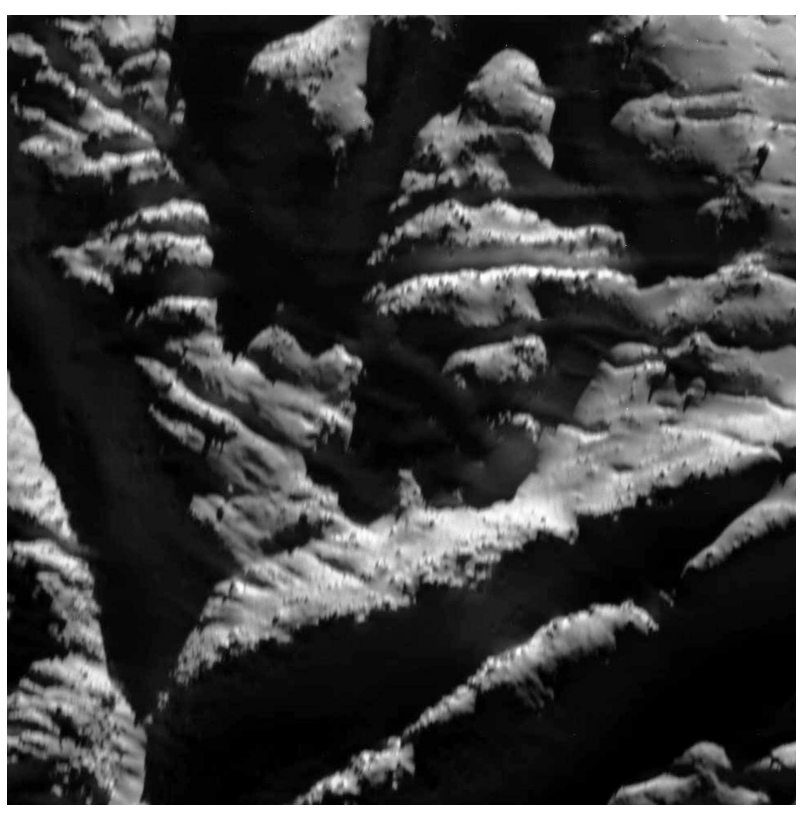

Fig. 2. Rough terrain at Enceladus' south pole, with boulders resting along the tops of high frozen ridges (edited from the original raw image to enhance detail). Image credits: NASA/JPL/Space Science Institute, Universe Today.

In this paper, we (1) outline the general IceMole design, (2) describe the specific design of the first two IceMole prototypes (IceMole 1 and IceMole 2) and report results from their field tests, (3) provide the current probe design for the EnEx/MIDGE project (EnEx-IceMole), (4) discuss the IceMole's potential for clean in situ analyses and sampling of subsurface ice and subglacial liquids, and (5) outline the way forward for advancing this technology.

\section{GENERAL IceMole DESIGN}

The concept of melting probes for deep ice research is not novel and such technology has been available since the early 1960s (Kasser, 1960; Philberth, 1962; Shreve, 1962; Aamot, 1968). These traditional probes, however, have three main drawbacks (Dachwald and others, 2013b):

1. they penetrate only vertically downwards

2. they cannot penetrate dust/dirt layers because sediment concentrates underneath the melting tip, causing thermal insulation and frictional resistance

3. in cold ice, they cannot be recovered from greater depths because the melting channel closes or refreezes behind the probe

To remedy these drawbacks, we have based the IceMole design on the novel concept of combined melting and mechanical propulsion with a melting head that features a rotating hollow ice screw (Fig. 3).

The screw is driven by a $25 \mathrm{~W}$ servo-controlled electric motor and a gear system. The screw presses the melting head against ice. This enhances conductive heat transfer into ice and aids steering in the desired direction, including probe motion upwards against gravity (this is, of course, only possible in solid ice; cavities exceeding the length of the screw (see Table 1) will stop the IceMole's upward motion and a surface firn layer can also not be penetrated). The 


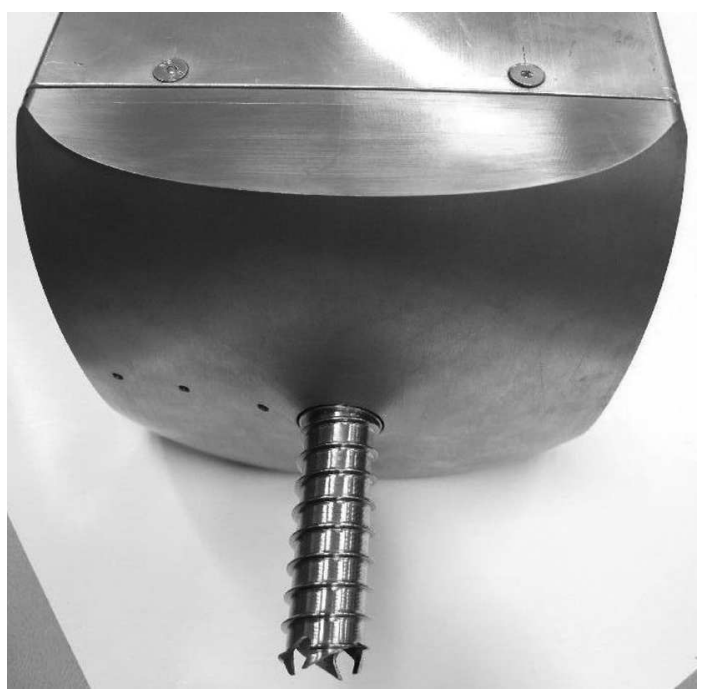

Fig. 3. IceMole 1 melting head with ice screw.

latter capability may be of particular importance for probe missions that include requirements for sample return. Furthermore, the probe is capable of penetrating layers of debris-ladden ice (there is, of course, a penetration limit in very dirty ice with thick debris layers, as is discussed later, and for obstacles exceeding the screw diameter (inner diameter is $1.5 \mathrm{~cm}$, outer diameter is $1.8 \mathrm{~cm})$ ). The current IceMole bodies have a rectangular tube shape with a $15 \mathrm{~cm} \times 15 \mathrm{~cm}$ cross section. Their length depends on the payload dimensions and the desired maneuverability. The rectangular shape of the IceMole counteracts the torque of the rotating ice screw (a cylindrical probe would spin in the melting channel during ice-screw operation). The IceMole can change melting direction by differential heating of the melting head, which generates a torque (perpendicular to the longitudinal axis of the IceMole) that forces the probe into a curve. Optional side-wall heaters may support its curve-driving capability. The required electric power for the melting head, the ice-screw motor, as well as for the payloads and the other subsystems, is generated by a surface generator (see Fig. 4) and transmitted via a three-conductor power cable. (The probe is powered with $230 \mathrm{~V} / 50 \mathrm{~Hz}$. Internally, $24 \mathrm{~V}$ d.c. is provided for the payload systems.)

Accumulated meltwater may be pumped out of the melting channel to prevent refreezing or, if this is not done, the cable may be uncoiled from the probe. For greater depths of several hundred meters, the cable can be packed into separate containers (each containing several tens of meters of cable) that are added to the IceMole. Communication and data transfer to the surface can also be done via the power cable or via an Ethernet cable. With its maneuverability and its ability to penetrate sediment layers, the IceMole can also follow layers of interest, thus allowing space-resolved in situ profile measurements, whereas traditional melting probes and conventional drills are only able to pierce such horizontal layers. Another advantage as compared to conventional drilling is that the IceMole can, in principle, operate autonomously, without a crew on the surface, thereby allowing weather-independent operations during the Arctic/Antarctic winter. One of the most significant advantages of the IceMole over conventional drilling, however, is its ability to cleanly deliver scientific instruments into deep ice and then recover them, and to cleanly collect

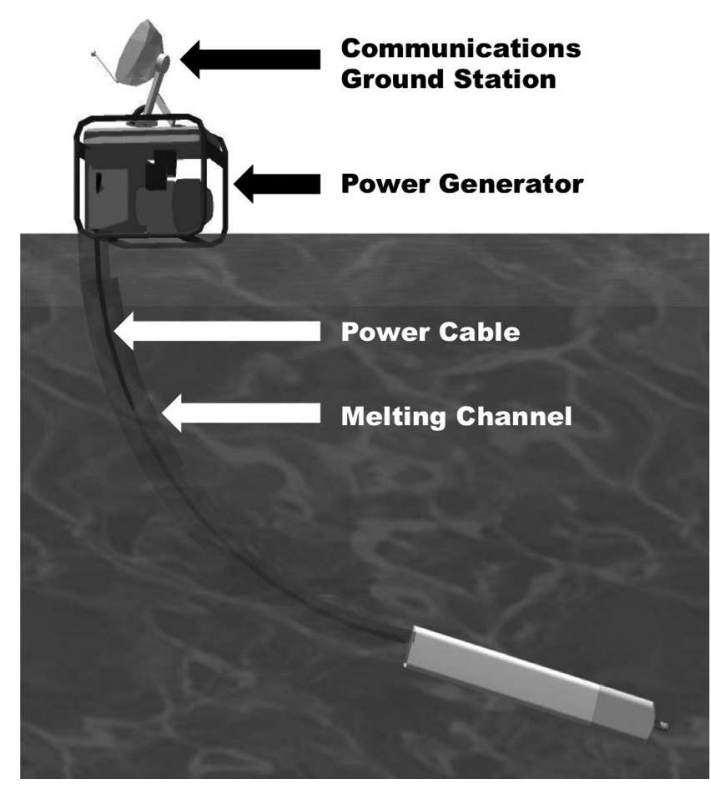

Fig. 4. IceMole operations concept (artist's impression).

samples of subglacial materials. The IceMole does not use any drilling fluid and may be sterilized before deployment, according to planetary protection standards (Rummel, 2010) and the Antarctic Code of Conduct for the Exploration and Research of Subglacial Aquatic Environments (NRC, 2007). Additionally, an optional system for in situ chemical decontamination of the probe within ice may be used. In contrast to conventional drills that reach the same depths, the IceMole also has a much smaller logistical footprint. Depending on the amount of gasoline required, all the equipment $(\sim 500 \mathrm{~kg}$ plus gasoline) fits into one or two helicopter sling loads.

\section{DESIGN AND FIELD TESTS OF THE FIRST IceMole PROTOTYPES}

\section{IceMole 1}

The first IceMole prototype (Fig. 5; Table 1), now referred to as IceMole 1, had a melting head with a power of $3.2 \mathrm{~kW}$, distributed over four heating zones.

The $0.87 \mathrm{~m}$ long probe was originally designed to collect ice samples. The hollow ice screw was thermally isolated from the melting head to allow collection of unmelted ice through the interior of the screw. Further up the ice screw, the crushed ice core could be visually inspected or imaged within an acrylic tube (see Fig. 5). Also, the hull had an acrylic window to enable imaging of the melting channel. A simple off-the-shelf camera was installed in the payload bay for testing purposes.

In September 2010, we successfully conducted three penetration tests on Morteratschgletscher (Fig. 6):

1. melting $45^{\circ}$ upwards for $\sim 1.5 \mathrm{~m}$, against gravity (Fig. 7 );

2. melting horizontally for $\sim 5 \mathrm{~m}$ (Fig. 8);

3. melting $45^{\circ}$ downwards for $\sim 3 \mathrm{~m}$, thereby penetrating three obstructing non-ice layers (made from material found on the glacier) and driving a curve with a radius of $\sim 10 \mathrm{~m}$ (Fig. 9). 


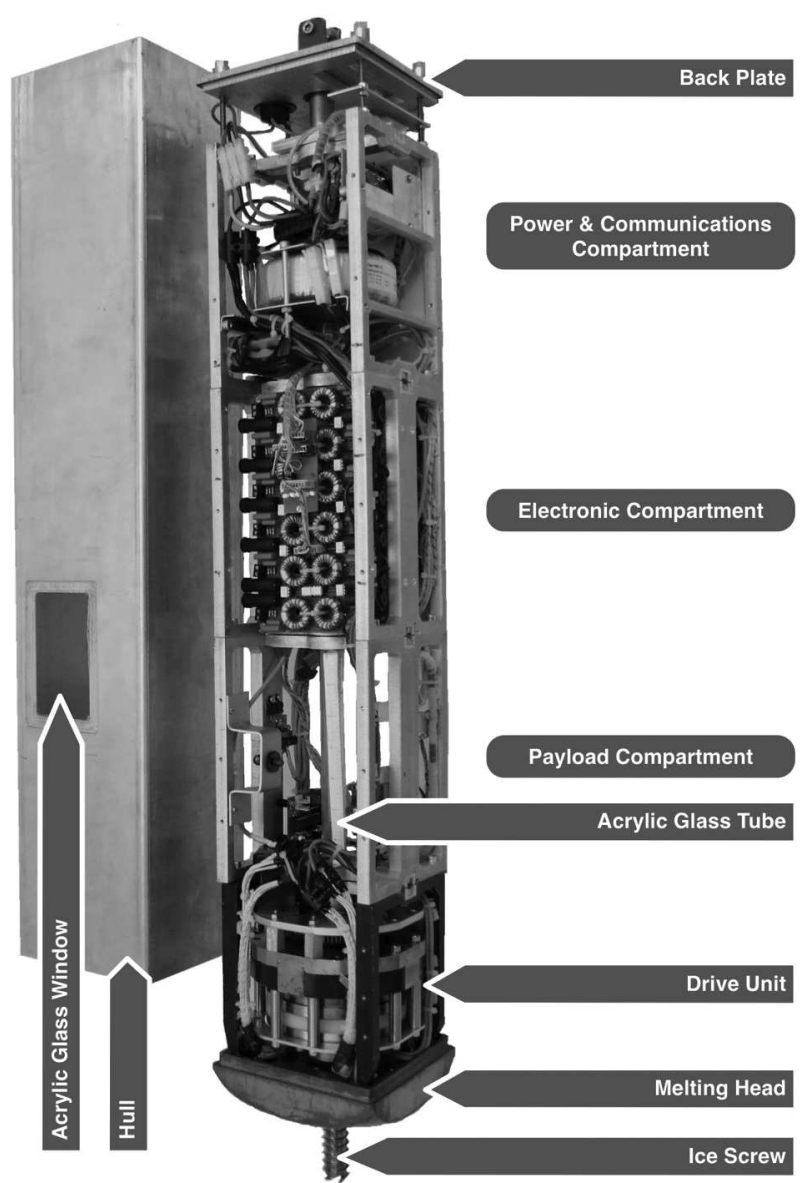

Fig. 5. IceMole 1 assembly view.

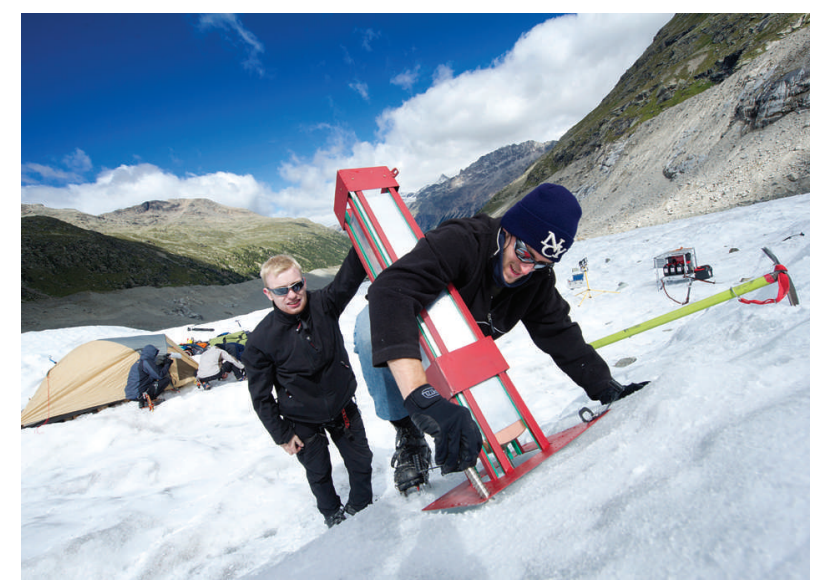

Fig. 6. Deployment of the IceMole 1 prototype on Morteratschgletscher in 2010.

The penetration velocity in each of the tests was only $\sim 0.3 \mathrm{~m} \mathrm{~h}^{-1}$ because of the still suboptimal matching between drive and melting power.

\section{IceMole 2}

Between 2010 and 2012, a second IceMole prototype, IceMole 2, was developed at FH Aachen University of Applied Sciences (Fig. 10; Table 1).

IceMole 2 had a more sophisticated heater control system, with 12 separately controllable heating cartridges in the parabolically shaped melting head and eight side-wall heaters. Both updates were intended to improve the probe's maneuverability and support its curve-melting capabilities. IceMole 2 weighed less than IceMole 1 and contained an attitude and position determination system. The melting velocity was increased to $\sim 1 \mathrm{~m} \mathrm{~h}^{-1}$.

Table 1. Technical data for the different IceMole probes

\begin{tabular}{|c|c|c|c|}
\hline & IceMole 1 & IceMole 2 & EnEx-IceMole \\
\hline Cross section & $15 \mathrm{~cm} \times 15 \mathrm{~cm}$ & $15 \mathrm{~cm} \times 15 \mathrm{~cm}$ & $15 \mathrm{~cm} \times 15 \mathrm{~cm}$ \\
\hline Shape of melting head & complanate & parabolic & complanate \\
\hline Max. heating power for melting head & $4 \times 800 W$ & $12 \times 200 W$ & $(8 \times 200 W)+(8 \times 160 W)$ \\
\hline Max. heating power for side-wall heaters & $\mathrm{N} / \mathrm{A}$ & $\begin{array}{l}\qquad 8 \times 300 \mathrm{~W} \\
\text { (partial coverage with const. heat distr) }\end{array}$ & $\begin{array}{l}\qquad 8 \times 1000 \mathrm{~W} \\
\text { (full coverage with linear heat distr.) }\end{array}$ \\
\hline Max. power for forward melting & $3.2 \mathrm{~kW}$ & $2.4 \mathrm{~kW}$ & $2.9 \mathrm{~kW}$ \\
\hline Max. power for curve driving & $1.6 \mathrm{~kW}$ & $1.8 \mathrm{~kW}$ & $5.0 \mathrm{~kW}$ \\
\hline Max. penetration velocity & $\sim 0.3 \mathrm{~m} \mathrm{~h}^{-1}$ & $\sim 1.0 \mathrm{~m} \mathrm{~h}^{-1}$ & $\sim 1.1 \mathrm{~m} \mathrm{~h}^{-1}$ \\
\hline Length (without ice screw) & $0.9 \mathrm{~m}$ & $1.2 \mathrm{~m}$ & $2.0 \mathrm{~m}$ \\
\hline Length of ice screw & $7 \mathrm{~cm}$ & $8.5 \mathrm{~cm}$ & $6 \mathrm{~cm}$ \\
\hline Ice-screw driving power & $25 \mathrm{~W}$ & $25 \mathrm{~W}$ & $25 \mathrm{~W}$ \\
\hline Mass & $\sim 30 \mathrm{~kg}$ & $\sim 25 \mathrm{~kg}$ & $\sim 60 \mathrm{~kg}$ \\
\hline Max. pressure & 1 bar & 5 bar & 5 bar \\
\hline Bus system & SPI & CAN & CAN, Ethernet \\
\hline Communications to surface & power-line modem & power-line modem & Ethernet and power-line modem \\
\hline Max. data rate to surface & $19.2 \mathrm{kbits}^{-1}$ & $19.2 \mathrm{kbits}^{-1}$ & $1000 \mathrm{Mbits}^{-1}$ \\
\hline Attitude and position determination system & no & simple & advanced \\
\hline Decontamination and sampling system & no & no & yes \\
\hline Obstacle and target detection system & no & no & yes \\
\hline Field tests & $\begin{array}{l}\text { Morteratschgletscher } \\
2010\end{array}$ & $\begin{array}{c}\text { Morteratschgletscher 2012, } \\
\text { Hofsjökull } 2012\end{array}$ & $\begin{array}{l}\text { Morteratschgletscher 2013, } \\
\text { Canada Glacier } 2013\end{array}$ \\
\hline Longest channel made & $\sim 5 \mathrm{~m}$ & $\sim 8 \mathrm{~m}$ & $\sim 25 \mathrm{~m}$ \\
\hline Min. curve radius & $\sim 10 \mathrm{~m}$ & N/A & $\sim 10 \mathrm{~m}$ \\
\hline
\end{tabular}

Notes: $\mathrm{N} / \mathrm{A}=$ not applicable. Max. power for curve driving $=(0.5 \times$ max. heating power $)$ for melting head $+(0.25 \times$ max. heating power $)$ for side-wall heaters . 


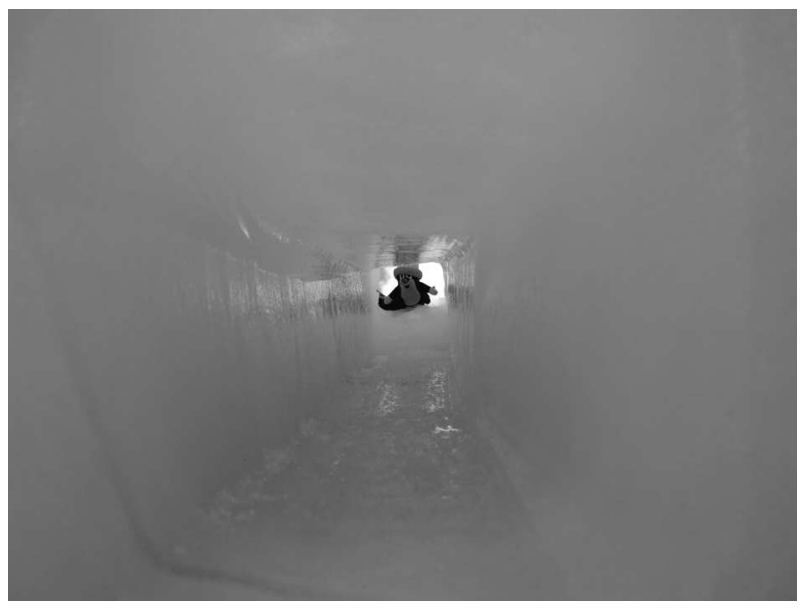

Fig. 7. First channel melted by IceMole 1 at Morteratschgletscher in 2010: $45^{\circ}$ upwards, length $\sim 1.5 \mathrm{~m}$.

In July and September 2012, we conducted several penetration tests on Morteratschgletscher and Hofsjökull. The original objective of the Hofsjökull tests was to demonstrate the recoverability of the IceMole by melting a standing U-channel, combining a downward leg, a $180^{\circ}$ curve and an upward leg. These tests, however, revealed that the parabolic shape of the melting head diminished, rather than improved, the probe's curve-melting capability, due to the inability to generate the required torque perpendicular to the longitudinal axis of the probe. Also, a longer ice screw was used, which further stabilized forward motion. Nevertheless, we were able to investigate the behavior of the IceMole during crevasse penetration (Fig. 11).

Although the curve-driving capability of IceMole 2 was less than expected, the tests demonstrated the capability and stability of the electronic subsystems and the software, as well as the probe's reliable operations.

\section{DESIGN AND FIRST FIELD TEST OF THE EnEx-IceMole}

The current design of the IceMole is adapted to subsurface investigations of terrestrial glaciers and ice sheets, but with the long-term goal of adapting the IceMole technology to

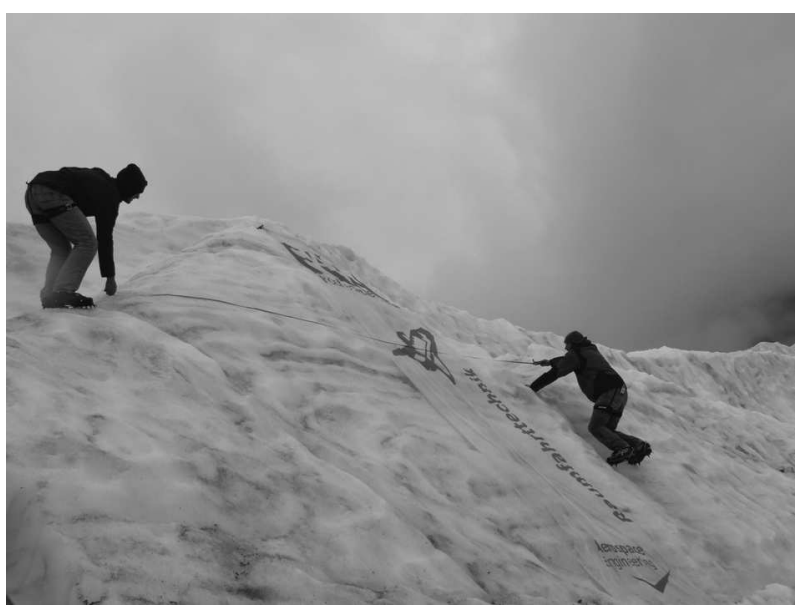

Fig. 8. Second channel melted by IceMole 1 at Morteratschgletscher in 2010: horizontal, length $\sim 5 \mathrm{~m}$.
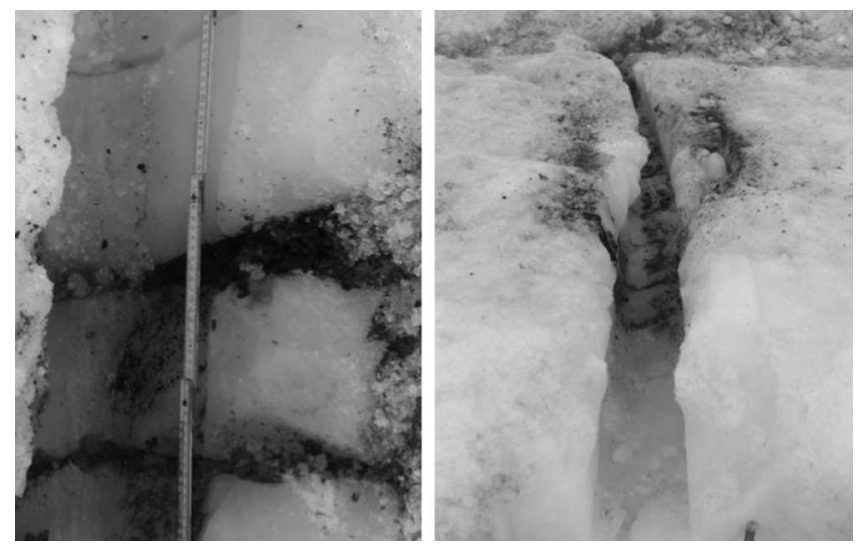

Fig. 9. Third channel melted by IceMole 1 at Morteratschgletscher in 2010: $45^{\circ}$ downwards, length $\sim 3 \mathrm{~m}$; penetration of $\sim 4 \mathrm{~cm}$ of dirt (found on the glacier); curve with a radius of $\sim 10 \mathrm{~m}$ (channel was opened afterwards).

extraterrestrial ice research. As a first step in this direction, a more advanced IceMole probe is currently under development as part of the EnEx project. This probe includes sophisticated systems for obstacle avoidance, target detection, and navigation in ice. The main technological objective of this project is to develop and test navigation in deep ice. This way, the EnEx project provides the first steps in preparing the IceMole and its navigation technology for extraterrestrial applications, especially for a mission to reach and sample Enceladus' plumes below the moon's icy surface. The EnEx-IceMole has an inertial measurement unit (IMU) and a magnetometer to measure its attitude. A second (reference) magnetometer will be installed at the surface ground station. Together with the advance of the ice screw, the attitude history from the IMU and the magnetometer will then be used to calculate the probe's trajectory. Four ultrasonic phased arrays in the melting head are designed to detect the targeted crevasse as well as potential obstacles in the ice. Additionally, acoustic pingers on the surface emit signals that are received by four separate onboard detectors. They allow for independent determination of the probe's position using the triangulation principle. A multi-sensor data fusion system will combine raw data streams from the navigation sensors to generate a consistent scenario and to display it in a user-friendly format to support the decision-making process of the human probe operator on the surface. In the future, this may serve as a basis for autonomous control of the probe. This system will also include a module to optimize the probe's trajectory in the ice with respect to parameters such as available resources, time and risk. For the time being, however, the EnEx-IceMole will demonstrate the suitability of the developed technologies for navigation only in a terrestrial analog

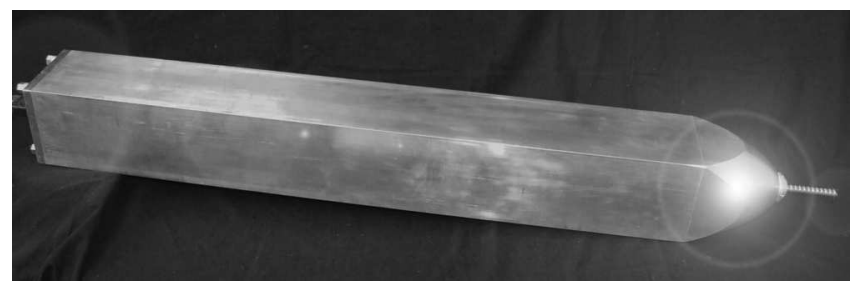

Fig. 10. IceMole 2. 
test environment. It is not yet designed for the much harsher space environment on Enceladus; due to complexity and cost, an Enceladus mission should not be expected in the next two decades.

The first field test of the EnEx-IceMole was conducted in June 2013 on Morteratschgletscher. The main objective of this field campaign was to test the stability and interoperability of the newly developed navigation subsystems and the evolutionary design changes in the IceMole subsystems. Another objective was to make first tests for the Clean Access and Sampling Subsystem. The field campaign has shown that, despite the increased length of the EnExIceMole (Table 1), the curve radius is between 8 and $11 \mathrm{~m}$.

\section{POTENTIAL FOR CLEAN IN SITU ANALYSIS AND SAMPLING}

Recovering samples from subglacial environments that are free of microbial and chemical contamination is important for two key reasons: (1) to maintain the scientific integrity of the samples collected and (2) to minimize the impact on the subglacial environment being studied. Guidelines have been established for research in subglacial systems by scientific and regulatory communities, and are detailed by the Code of Conduct (CoC) for the Exploration and Research of Subglacial Aquatic Environments, issued by the Scientific Committee on Antarctic Research (SCAR) Action Group (NRC, 2007; Doran and Vincent, 2011). The CoC recognizes the ecological importance and pristine nature of subglacial habitats and recommends a path forward towards clean exploration. Our approach to sampling subglacial environments with the IceMole is to strive for the cleanliness stringencies of a space mission. The Committee on Space Research (COSPAR) of the International Council for Science has a planetary protection policy based on international consensus. In brief, missions with a lander or probe that will come into direct contact with an icy body that is of interest for biological, chemical or origin-of-life studies and is considered to provide the minimal requirements for life must document their planetary protection plan and provide reports throughout the mission. COSPAR requires contamination control, an organics and bioload inventory and a contamination analysis plan. It further requires implementing procedures for sterilizing contacting hardware and monitoring of bioburden (Rummel, 2010). The US and European space agencies, NASA and ESA, have also detailed instrument preparation protocols for the exploration of icy bodies in our Solar System for planetary protection, in the NASA Handbook for the Microbial Examination of Space Hardware (NASA, 2010). The same rationale applies to both subglacial and extraterrestrial environments in that the exploration of these systems requires cleanliness for both sample integrity and conservation of the pristine nature of these systems.

The Antarctic Treaty CoC on subglacial exploration (NRC, 2007) recommends that the number of microbial cells on instruments entering subglacial environments should not exceed the concentration of microbes in the basal glacial ice being passed through. The microbial cell concentration in the Taylor Glacier ice surrounding the Blood Falls crevasse is $2.3 \times 10^{3}$ cells $\mathrm{mL}^{-1}$. For comparison, subglacial outflow from Blood Falls contains cells in the range $10^{4}-\left(7.6 \times 10^{5}\right)$ cells $\mathrm{mL}^{-1}$ (Mikucki and Priscu, 2007). We will routinely monitor cell numbers in the meltwater

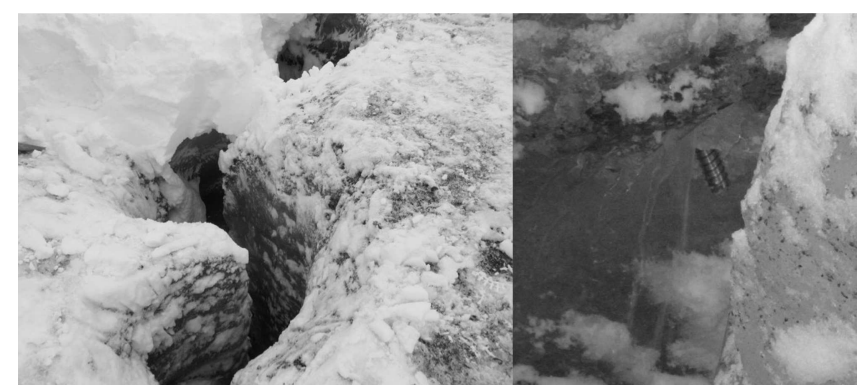

Fig. 11. Crevasse (moulin) on Hofsjökull (left) that was penetrated with IceMole 2 (right).

pumped to the surface by the IceMole. We intend to clean the exterior surfaces of the IceMole prior to deployment using $3 \% \mathrm{H}_{2} \mathrm{O}_{2}$. While this is a strong oxidizer that is often used for cleaning surfaces, it also readily breaks down to $\mathrm{O}_{2}$ and $\mathrm{H}_{2} \mathrm{O}$, making it an ideal cleaning solvent. While it is not possible to have zero impact when investigating subglacial environments, our goal is that our impact should be minimal or transient.

The IceMole concept is a viable approach for the clean deployment of scientific instruments into deep ice, and their recovery. Recovery can be accomplished by melting upwards until the probe reaches the surface (the probe cannot melt upwards in firn, in which the screw has not enough grip to support the weight of the probe) or by retracting the probe back through the melting channel. In the former case, the water may freeze behind the probe, whereas in the latter case, the water must not refreeze in the melting channel (rather it can be pumped out of the melting channel). Contrary to conventional ice-drilling methods, the IceMole does not utilize drilling fluids and may by sterilized according to planetary protection standards before its subglacial deployment. Because subglacial materials are sampled by the hollow ice screw at the tip of the probe, they do not come into contact with the exterior of the IceMole. Currently, the ingested ice core is crushed by the ice screw (being an intentional feature for mountaineers), but this may be avoided by using a different cutting geometry. Because the ice screw is thermally isolated from the melting head, the ingested ice does not melt inside the ice screw and can be analyzed within an acrylic glass tube in the payload compartment even at some distance upstream of the ice screw. Optionally, the hull can also be equipped with an acrylic glass window that gives optical payload systems access to the wall of the melting channel.

\section{IceMole OPERATIONS AT BLOOD FALLS}

Our target for the initial testing of EnEx for the collection of subglacial samples is Blood Falls, a unique glacial feature at the terminus of Taylor Glacier. Blood Falls forms where ironrich subglacial liquid discharges to the surface. The ferrous iron in the subglacial liquid rapidly oxidizes at the surface, staining the glacier snout blood-red. Blood Falls was selected as a target for IceMole sampling because (1) there is significant scientific merit in understanding the ecology, geochemistry and thermal regime of this feature, (2) extra measures for clean sampling are required due to the pristine nature and special protection of the system under the Antarctic Treaty, making the EnEx an ideal tool at this 


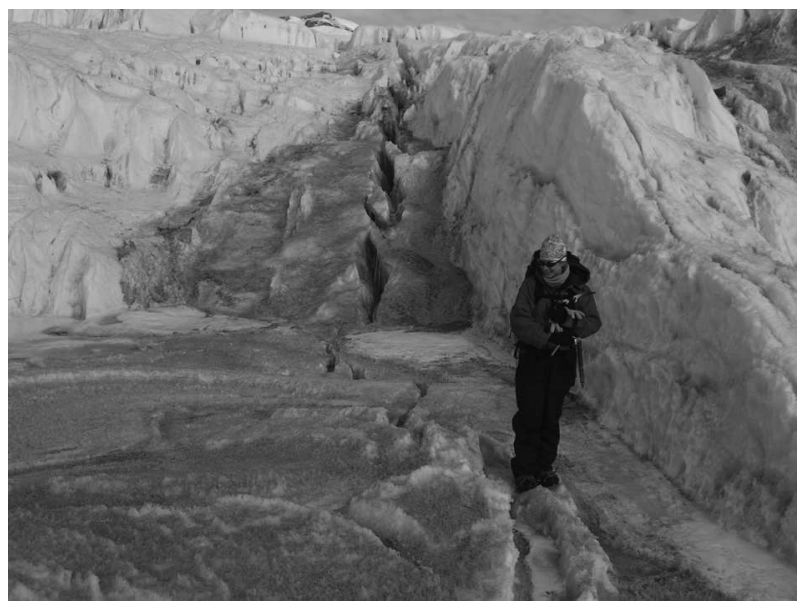

Fig. 12. Blood Falls crevasse. Image credit: Harry Keys.

sensitive site, and (3) Blood Falls is a terrestrial analog to the cryovolcanic cracks on Enceladus. The subglacial reservoir has never been directly sampled, but the release at Blood Falls, which has been analyzed, is saline and iron-rich and contains an active community of microorganisms.

Biogeochemical measurements indicate that the source to this reservoir is marine; details on the biogeochemistry of the brine outflow at Blood Falls have been described elsewhere (Keys, 1979; Mikucki and others, 2004, 2009; Lyons and others, 2005; Mikucki and Priscu, 2007). While the hydrology is poorly understood, geophysical surveys indicate that a brine reservoir likely exists $\sim 5 \mathrm{~km}$ from the glacier snout (Hubbard and others, 2004) and migrates along the glacier bed prior to release at Blood Falls. The marine biogeochemistry of the outflow supports the idea that this brine is a remnant of an ancient fjord that occupied the Taylor Valley during the Tertiary (Kennett and Hodell, 1993; Lyons and others, 2005; Pollard and DeConto, 2009), though this is not a confirmed fact. This brine now emerges through a distinct englacial conduit, Blood Falls (Fig. 12).

The MIDGE/EnEx project will improve our understanding of this unique subglacial ecosystem through detailed geophysical analyses and clean sampling of brine fluid traveling through the englacial conduit.

We will first demonstrate clean access of the EnEx system on Canada Glacier in November/December 2013, prior to sampling Blood Falls in the 2014/15 austral summer. Ultimately, probing will be conducted at the conduit draining Blood Falls. Blood Falls is part of the Antarctic Specially Managed Area (ASMA) under the Antarctic Conservation Act (ACA) and has recently been designated an Antarctic Specially Protected Area (ASPA). The ASPA designation requires greater protection in accordance with the Management Plan for Antarctic Specially Protected Area No. 172: Lower Taylor Glacier and Blood Falls, McMurdo Dry Valleys, Victoria Land. Thus our clean-access plan is an important component of our sampling requirements.

The components of the IceMole as well as the other equipment will be packed into sterile double-wall polypropylene sacks prior to shipment. The laboratory-based cleaning and sterilization of each item will be performed by a combination of at least two appropriate physical and chemical methods. The principal physical methods applied include autoclaving (typically $121^{\circ} \mathrm{C}$ for $30 \mathrm{~min}$ ), dry heat (typically $90^{\circ} \mathrm{C}$ for 15 hours), and exposure to germicidal

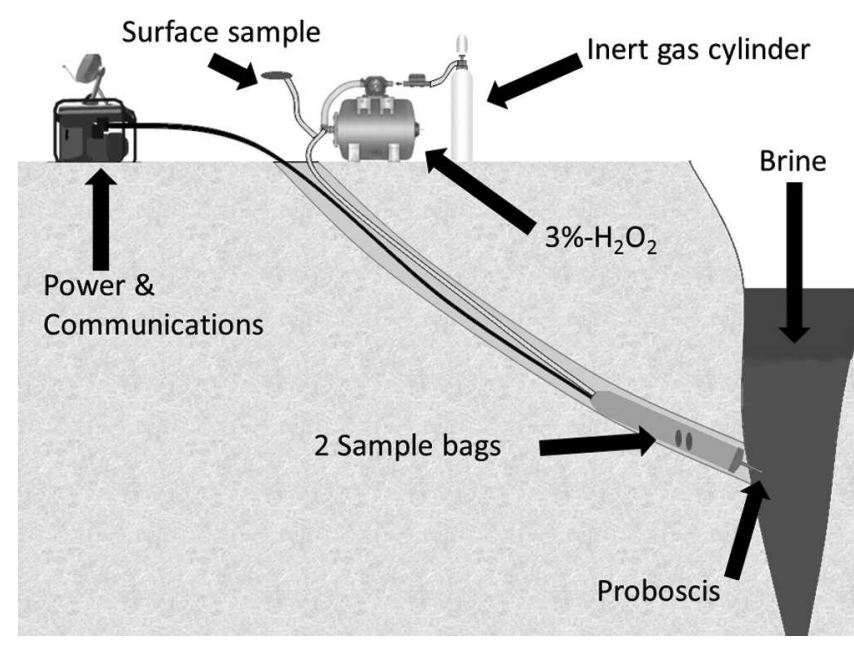

Fig. 13. EnEx-IceMole operations concept at the Blood Falls crevasse (artist's impression).

ultraviolet irradiation (typically $254 \mathrm{~nm}, 10 \mathrm{~mW} \mathrm{~s} \mathrm{~cm}^{-2}$ ). The chemical IceMole treatment mainly relies on (1) oxidative disruption of biomolecules agents and (2) detergent action. Typical agents used are a 5\% sodium hypochlorite solution, and a series of detergent mixtures (Korsolex basic ${ }^{\circledR}$, Bacillol $\mathrm{AF}^{\circledR}$ and Mucasol $\left.{ }^{\circledR}\right)$. The choice of the item-specific decontamination protocol in each case is mainly dictated by the material properties (e.g. resistance to the oxidative agent treatment) and by the dimensions of the items. Sterility of the processed equipment will be tested by both epifluorescence microscopy and cfu (colony-forming units) test using a standard R2A culture medium.

The instrument will arrive at the field site cleaned to the specifications described above, and, in order to meet the above clean-access requirements, our strategy includes a field-based cleaning step for decontamination of the instrument during handling, monitoring of any biological or chemical contaminates prior to deployment, and an in situ decontamination of the sampling mechanisms immediately before sample collection. The interior and exterior parts of the IceMole will be decontaminated in a heated sampling hut with a $3 \%$ hydrogen peroxide $\left(\mathrm{H}_{2} \mathrm{O}_{2}\right)$ solution. The hut will be closed off to drilling activities to minimize the introduction of contaminants. To determine the efficacy of our approach, we will assess the bioburden on the IceMole/MIDGE probe and its instruments before and after cleaning and following sampling to monitor the presence of (1) active cells, (2) viable cells, (3) total cells, (4) organic and (5) chemical contamination. Our approach follows the NASA Handbook for the Microbial Examination of Space Hardware (NASA, 2010), which details procedures developed to meet the requirements of NASA's Planetary Protection and Space and Life Sciences Programs.

Clean sampling will be done by the IceMole's Clean Access and Sampling Subsystem (CASS). Figure 13 illustrates the operations concept at the Blood Falls crevasse. The ultrasound sensors will detect the crevasse and stop the IceMole shortly before it taps the crevasse to initiate the decontamination step. First, the remaining meltwater in the melting channel will be pumped out through the meltwater tube by a pumping system located within the IceMole. Next, $3 \% \mathrm{H}_{2} \mathrm{O}_{2}$ will be injected into the melting channel through five orifices located at the melting head. The ice screw will 
rotate back and forth until it is fully covered with the decontamination solution. Injection pressure is produced by an inert gas (argon or nitrogen) cylinder that is connected to a pressure vessel filled with $10 \mathrm{~L}$ of $3 \% \mathrm{H}_{2} \mathrm{O}_{2}$. These two parts will be located at the surface ground station and connected to the IceMole by the decontamination/sampling tube. The operating pressure for the decontamination system is $\sim 10$ bar. After an appropriate reaction time of $15 \mathrm{~min}$, the decontamination fluid will be removed from the melting channel and the sampling step will start. The IceMole will tap the water-filled crevasse with a proboscis that is deployed from the interior of the ice screw. The proboscis is extended by a pneumatic system within the IceMole. A first water sample will be pumped to the surface for cleanliness assurance with a second pumping system. It will remove all residual $\mathrm{H}_{2} \mathrm{O}_{2}$ in the connected decontamination/sampling tube to the surface. Once the cleanliness of the sampled brine has been confirmed by analysis on the surface (using conductivity measurements), pristine brine samples will be collected into two internal, sterile, gas-tight sample bags $(0.5 \mathrm{~L}$ each). The sampling bags are located in two separate gas-tight boxes and connected through a series of valves to the proboscis. The bags are filled by producing an under-pressure in the sample bag boxes; this fills the bags within $\sim 180 \mathrm{~s}$. All valves, pumps and sample temperatures are controlled by a micro-controller and a customized software solution. In addition to its main function, the CASS will provide an emergency rescue system for the IceMole in case of a complete system failure and loss of communications. In this case, the pressure vessel of the decontamination system on the surface will be filled with clean hot water and connected with the meltwater tube. The hot water will be forced through this tube to the orifices at the melting head and will release the ice screw from the ice, allowing the IceMole to be extracted through the melting channel and returned to the surface. The decontamination system was tested and validated during a field test on Morteratschgletscher in June 2013. The sampling system is currently set up as an engineering model and was verified in laboratory tests. Next steps include the complete integration and testing of the CASS. Validation of the fully integrated subsystem in a relevant environment will take place during the field test at Canada Glacier.

\section{SUMMARY AND CONCLUSIONS}

Offering numerous advantages as compared to both conventional drilling and traditional melting probes, the novel IceMole technology is a promising approach for clean access to subglacial environments and clean in situ analysis and sampling of subsurface materials. While other methods may be faster and may offer more instrumentation options, it may fill a niche in this area. It is especially promising for future extraterrestrial applications, where the required mass and cost render conventional drilling infeasible. The IceMole technology was successfully tested between 2010 and 2012 with two generations of probes on glaciers in Switzerland and Iceland. A more advanced third-generation probe is currently being developed by a research consortium of six German universities. It was sucessfully tested in June 2013 in Switzerland and will be further tested in November/ December 2013 at Canada Glacier. In the 2014/15 austral summer, it will be deployed at Blood Falls to take clean samples of subglacial brine.

\section{ACKNOWLEDGEMENTS}

The IceMole team thanks Thorsteinn Thorsteinsson and his colleagues at the Icelandic Meteorological Office for their kind field-test support at Hofsjökull. The Enceladus Explorer project is based on an idea and initiative of the DLR Space Administration. It is funded by resolution of the German parliament under project No. 50 NA 1206. The Enceladus Explorer collaboration comprises the following universities: FH Aachen University of Applied Sciences; Bundeswehr University Munich; University of Bremen; Braunschweig University of Technology; RWTH Aachen University; and University of Wuppertal. The MIDGE project is funded by the NSF Office of Polar Programs under grants ANT1144178 to J.M. and ANT-1144192 to S.T.

\section{REFERENCES}

Aamot HWC (1968) Instrumented probes for deep glacial investigations. J. Glaciol., 7(50), 321-328

Chyba CF and Phillips CB (2007) Europa. In Sullivan WT and Baross JA eds. Planets and life: the emerging science of astrobiology. Cambridge University Press, Cambridge

Cruikshank DP and 9 others (2005) A spectroscopic study of the surfaces of Saturn's large satellites: $\mathrm{H}_{2} \mathrm{O}$ ice, tholins, and minor constituents. Icarus, 175(1), 268-283 (doi: 10.1016/j.icarus. 2004.09.003)

Dachwald B, Xu C, Feldmann M and Plescher E (2011) Development of a novel subsurface ice probe and testing of the first prototype on the Morteratsch Glacier. Geophys. Res. Abstr., 13, EGU2011-4943

Dachwald B, Feldmann M, Espe C, Plescher E, Xu C and Enceladus Explorer Collaboration (2012) Development and testing of a maneuverable subsurface probe that can navigate autonomously through deep ice. In Abstract book: 9th International Planetary Probe Workshop (IPPW-9), 16-22 June 2012, Toulouse, France. NASA, 95 http://solarsystem.nasa.gov/docs/ippw9_abstract_ book_final_light.pdf

Dachwald B, Feldmann M, Plescher E, Konstantinidis RF and Enceladus Explorer Collaboration (2013a) Enceladus Explorer: a maneuverable subsurface probe for autonomous navigation through deep ice. In Proceedings of the 63rd International Astronautical Congress (IAC 2012), 1-5 October 2012, Naples Italy, A3.5.7. International Astronautical Federation, Paris/ Curran Associates, Red Hook, NY, 1756-1766

Dachwald B, Ulamec S and Biele J (2013b) Clean in situ subsurface exploration of icy environments in the solar system. In De Vera J-P and Seckbach J eds. Habitability of other planets and satellites. Springer, Dordrecht, 367-397

Doran PT and Vincent WF (2011) Environmental protection and stewardship of subglacial aquatic environments. In Siegert MJ, Kennicutt $\mathrm{MCl}$ and Bindschadler RA eds. Antarctic subglacial aquatic environments. (Geophysical Monograph Series 192) American Geophysical Union, Washington, DC, 149-157

Greenberg R (2005) Europa - the ocean moon: search for an alien biosphere. Springer-Praxis, Chichester

Hendrix AR, Hansen CJ and Holsclaw GM (2010) The ultraviolet reflectance of Enceladus: implications for surface composition. Icarus, 206(2), 608-617 (doi: 10.1016/j.icarus.2009.11.007)

Hubbard A, Lawson W, Anderson B, Hubbard B and Blatter H (2004) Evidence for subglacial ponding across Taylor Glacier, Dry Valleys, Antarctica. Ann. Glaciol., 39, 79-84

Jakosky BM, Westall F and Brack A (2007) Mars. In Sullivan WT and Baross JA eds. Planets and life: the emerging science of astrobiology. Cambridge University Press, Cambridge, 357-387

Kargel JS (2006) Enceladus: cosmic gymnast, volatile miniworld. Science, 311(5766), 1389-1391 (doi: 10.1126/science.1124495) 
Kasser P (1960) Ein leichter thermischer Eisbohrer als Hilfsgerät zur Installation von Ablationsstangen auf Gletschern. Geofis. Pura Appl., 45(1), 97-114

Kennett JP and Hodell DA (1993) Evidence for relative climatic stability of Antarctica during the Early Pliocene: a marine perspective. Geogr. Ann. A, 75(4), 205-220

Keys JR (1979) Saline discharge at the terminus of the Taylor Glacier. Antarct. J. US, 14(5), 82-85

Lyons WB and 8 others (2005) Groundwater seeps in Taylor Valley, Antarctica: an example of a subsurface melt event. Ann. Glaciol., 40, 200-206 (doi: 10.3189/172756405781813609)

Mann A (2010) The IceMole cometh. Nature News (doi: 10.1038/ news.2011.261)

McKay CP, Porco CC, Altheide T, Davis WL and Kral TA (2008) The possible origin and persistence of life on Enceladus and detection of biomarkers in the plume. Astrobiology, 8(5), 909-919 (doi: 10.1089/ast.2008.0265)

Mikucki JA and Priscu JC (2007) Bacterial diversity associated with Blood Falls, a subglacial outflow from the Taylor glacier, Antarctica. Appl. Environ. Microbiol., 73(12), 4029-4039 (doi: 10.1128/AEM.01396-06)

Mikucki JA, Foreman CM, Sattler B, Lyons WB and Priscu JC (2004) Geomicrobiology of Blood Falls: an iron-rich saline discharge at the terminus of the Taylor Glacier, Antarctica. Aquat. Geochem., 10(3-4), 199-220 (doi: 10.1007/s10498-004-2259-x)

Mikucki JA and 8 others (2009) A contemporary microbially maintained subglacial ferrous 'ocean'. Science, 324(5925), 397-400 (doi: 10.1126/science.1167350)

NASA (2010) Handbook for the microbial examination of space hardware. (NASA Technical Handbook NASA-HDBK-6022) National Aeronautics and Space Administration, Washington, DC
National Research Council (NRC) (2007) Exploration of Antarctic subglacial aquatic environments: environmental and scientific stewardship. National Academies Press, Washington, DC

Pappalardo RT, McKinnon WB and Khurana KK eds. (2009) Europa. University of Arizona Press, Tucson, AZ

Parkinson CD and 7 others (2007) Enceladus: Cassini observations and implications for the search for life. Astron. Astrophys., 463(1), 353-357 (doi: 10.1051/0004-6361:20065773)

Patthoff DA and Kattenhorn SA (2011) A fracture history on Enceladus provides evidence for a global ocean. Geophys. Res. Lett., 38(18), L18201 (doi: 10.1029/2011GL048387)

Philberth K (1962) Une méthode pour mesurer les températures à I'intérieur d'un Inlandsis. C. R. Acad. Sci. [Paris], 254(22), 3881-3883

Pollard D and DeConto RM (2009) Modelling West Antarctic ice sheet growth and collapse through the past five million years. Nature, 458(7236), 329-332 (doi: 10.1038/nature07809)

Postberg F, Schmidt J, Hillier J, Kempf S and Srama R (2011) A saltwater reservoir as the source of a compositionally stratified plume on Enceladus. Nature, 474(7353), 620-622 (doi: 10.1038/nature10175)

Rummel JD (2010) Interplanetary spaceflight regulatory environment - planetary protection. In Blockley R and Shyy W eds. Encyclopedia of Aerospace Engineering. Wiley-Blackwell

Shreve RL (1962) Theory of performance of isothermal solid-nose hotpoints boring in temperate ice. J. Glaciol., 4(32), 151-160

Tokano T ed. (2005) Water on Mars and life. Springer, Berlin

Waite $\mathrm{JH}$ and 15 others (2009) Liquid water on Enceladus from observations of ammonia and ${ }^{40} \mathrm{Ar}$ in the plume. Nature, 460(7254), 487-490 (doi: 10.1038/nature08153) 